\title{
ŚWIADCZENIA RENTOWE DLA OSÓB BEZPOŚREDNIO POSZKODOWANYCH W WYPADKACH DROGOWYCH
}

\begin{abstract}
Streszczenie. Wypadki drogowe są poważnym problemem społecznym. Obecnie państwa wysoko rozwinięte przyjęły, że ofiary ruchu drogowego powinny być traktowane nie jako uboczny skutek podwyższonej mobilności, lecz jako istotny problem zdrowia publicznego. W opracowaniu przedstawiono zarówno analizę interpretacyjną i ilościową roszczeń przysługujących osobom poszkodowanym w wypadkach drogowych, jak i aktualną tendencję w obszarze świadczeń rentowych.

Słowa kluczowe: koszty leczenia, świadczenia rentowe, wypadki drogowe.
\end{abstract}

\section{WPROWADZENIE}

W Polsce, podobnie jak w innych krajach, wypadki drogowe są poważnym problemem społecznym. Dostrzegając rozmiar zjawiska, państwa wysoko rozwinięte przyjęły obecnie, że ofiary ruchu drogowego powinny być traktowane nie jako uboczny skutek podwyższonej mobilności, lecz jako istotny problem zdrowia publicznego.

Ubezpieczenie odpowiedzialności cywilnej posiadaczy pojazdów mechanicznych stanowi zarówno instrument ochrony ekonomicznej podmiotu odpowiedzialnego, jak i źródło kompensacji strat doznanych przez podmioty poszkodowane (Kwiecień 2010: 5).

Celem opracowania jest analiza interpretacyjna i ilościowa roszczeń przysługujących osobom poszkodowanym w wypadkach drogowych z tytułu ubezpieczenia OC posiadaczy pojazdów mechanicznych oraz zbadanie aktualnej tendencji w obszarze świadczeń rentowych, którym przypisuje się duże znaczenie społeczne.

\section{KOSZTY WYPADKÓW DROGOWYCH}

Wypadki drogowe są dużym obciążeniem społeczno-ekonomicznym każdego kraju. Jest to problem, który mimo że bezpośrednio dotyka tylko uczestnika wypadku, to generuje szereg skutków.

\footnotetext{
*Uniwersytet Łódzki, Wydział Ekonomiczno-Socjologiczny, Katedra Ubezpieczeń.
} 
Straty materialne są dość łatwe do oszacowania z uwagi na ich określoną wartość rynkową. Trudniejsze jest oszacowanie strat ludzkich związanych z zabitymi i rannymi. Głównym składnikiem tych strat jest utrata życia lub zdrowia przez ofiarę, a do tego dochodzi jeszcze cierpienie oraz żal ofiary i bliskich.

Do wymiernych kosztów zdarzeń drogowych można zaliczyć:

- koszty naprawy uszkodzonych pojazdów;

- koszty leczenia osób rannych;

- koszty świadczeń z tytułu niezdolności do pracy lub poniesionych z tego tytułu strat;

- koszty zasiłków chorobowych, rehabilitacyjnych i pogrzebowych;

- koszty wypłacanych świadczeń rentowych;

- koszty likwidacji skutków tych zdarzeń:

- praca policji,

- praca służb ratownictwa drogowego,

- praca straży pożarnych,

- praca pogotowia ratunkowego i personelu medycznego,

- praca służb odpowiedzialnych za usunięcie zanieczyszczeń na jezdni i naprawienie szkód w technicznych elementach dróg.

Wymienione koszty ponoszą zakłady ubezpieczeń - wypłacając odszkodowania i świadczenia (w tym renty) osobom poszkodowanym, wynikające z zawartych umów ubezpieczeń odpowiedzialności cywilnej posiadaczy pojazdów mechanicznych i auto-casco; Zakład Ubezpieczeń Społecznych i Kasa Rolniczego Ubezpieczenia Społecznego - wypłacając zasiłki chorobowe, rehabilitacyjne czy świadczenia rentowe ${ }^{1}$; a także Narodowy Fundusz Zdrowia w przypadku leczenia osób poszkodowanych. Jednak nie bez znaczenia są też koszty związane z pracą ww. służb, które ponosi całe społeczeństwo.

Poziom kosztów generowanych w konsekwencji powstania szkód osobowych w wypadkach drogowych zależy m.in. od sytuacji gospodarczej, cen towarów i usług oraz poziomu zamożności społeczeństwa. Należy tu jeszcze uwzględnić szkody tzw. transgraniczne, w przypadku których koszty mogą być zdecydowanie wyższe (Maśniak 2010: 73).

W obszarze analizy kosztów wypadków drogowych na uwagę zasługuje jeszcze jeden fakt, a mianowicie koszty pośrednie, które związane są głównie ze zmniejszoną produktywnością poszkodowanych wskutek wypadków. Determinantami utraty produktywności w wyniku wypadku drogowego są (Maciąg 2008: 207-209):

- czasowe nieobecności w pracy, które związane są z leczeniem poszkodowanych;

- ciągłe lub długoterminowe niepełnosprawności;

- przedwczesna umieralność.

${ }^{1}$ Świadczenia wypłacane przez ZUS i KRUS wynikają z faktu wcześniejszego opłacania składek na ubezpieczenie społeczne poszkodowanego. 


\section{WYNAGRODZENIA SZKÓD WYRZĄDZONYCH OSOBOM BEZPOŚREDNIO POSZKODOWANYM W WYPADKACH DROGOWYCH Z TYTUŁU UBEZPIECZENIA OC POSIADACZY POJAZDÓW MECHANICZNYCH}

Pojęcie odpowiedzialności cywilnej jest obok własności jedną z podstawowych instytucji, na jakich opiera się system prawa cywilnego.

„Odpowiedzialność cywilna jest to odpowiedzialność rozumiana jako: przewidziany w przepisach prawa cywilnego obowiązek ponoszenia materialnych konsekwencji zachowania własnego lub innych osób, a także innych zdarzeń, z którymi kodeks cywilny (Dz. U. 1964 nr 16, poz. 93 z późn. zm.) łączy ten skutek" (Rybicki 1980: 393).

Ubezpieczenia odpowiedzialności cywilnej stanowią szczególną kategorię ubezpieczeń gospodarczych z racji istoty, charakteru prawnego i pełnionych funkcji. W ubezpieczeniu odpowiedzialności cywilnej ubezpieczyciel zobowiązuje się do zapłaty odszkodowania bądź świadczenia za szkody wyrządzone osobom trzecim, względem których odpowiedzialność za szkodę ponosi ubezpieczający albo osoba trzecia, na której rzecz została zawarta umowa ubezpieczenia (Czachórski 1995: 379).

Odpowiedzialność ubezpieczyciela za skutki wypadku drogowego opiera się na art. 34 ustawy o ubezpieczeniach obowiązkowych (Dz. U. 2003 nr 124, poz. 1152 z późn. zm.) oraz art. 436 k.c. w związku z art. 435 k.c. Ubezpieczyciel, ponoszący odpowiedzialność w granicach odpowiedzialności cywilnej sprawcy wypadku drogowego, zobowiązany jest do naprawienia szkody, która pozostaje w normalnym związku przyczynowym z wypadkiem drogowym - art. $361 \S 1$ k.c. (Olędzka 2012: 32).

Z ubezpieczenia OC posiadaczy pojazdów mechanicznych przysługuje odszkodowanie, jeżeli posiadacz lub kierujący pojazdem obowiązani są do odszkodowania za związaną z ruchem tego pojazdu szkodę, której następstwem jest śmierć, uszkodzenie ciała, rozstrój zdrowia bądź też utrata, zniszczenie lub uszkodzenie mienia.

Odnosząc się do art. 36 ust. 1 ustawy o ubezpieczeniach obowiązkowych, to odszkodowanie ustala się i wypłaca w granicach odpowiedzialności cywilnej posiadacza lub kierującego pojazdem, najwyżej jednak do wysokości ustalonej sumy gwarancyjnej. Reasumując, przepisy kodeksu cywilnego decydują nie tylko o tym, czy zachodzi odpowiedzialność posiadacza lub kierującego pojazdem, lecz także o zakresie jego odpowiedzialności odszkodowawczej (Bieniek 2011: 105-106).

Szkoda osobowa to uszkodzenie ciała, spowodowanie rozstroju zdrowia, śmierć. W tym przypadku naruszone zostaje najistotniejsze dobro człowieka, jakim jest jego zdrowie. Kodeks cywilny wymienia cały katalog roszczeń możliwych do dochodzenia w sytuacji doznania szkody osobowej. Szczególne 
znaczenie w przedmiotowym zakresie mają przepisy art. 444 do 446 k.c. Natura tych roszczeń jest złożona. Normy kodeksowe dają tylko ogólne wskazówki kreujące proces odszkodowawczy. Każdy poszkodowany to indywidualna osoba i takie też jest jej odczuwanie następstw wypadku. W związku z tym potrzeba pewnej swobody, ale już nie dowolności. Wypełnieniem norm kodeksowych jest praktyka, a szczególnie orzecznictwo sądowe. Poszczególne roszczenia są uzależnione od siebie. Bezpośrednio poszkodowany ${ }^{2}$ ma prawo do odszkodowania z różnych tytułów, ocenianych odrębnie, a są nimi: pokrycie wszelkich kosztów, zadośćuczynienie za doznaną krzywdę, renta.

\section{Pokrycie wszelkich kosztów}

Podstawą prawną roszczeń o pokrycie wszelkich kosztów wynikłych $z$ uszkodzenia ciała lub rozstroju zdrowia jest art. $444 \S 1$ k.c. Na żądanie poszkodowanego zobowiązany do naprawienia szkody powinien wyłożyć z góry sumę potrzebną na koszty leczenia, a jeżeli stał się inwalidą, także sumę potrzebną na koszty przygotowania do innego zawodu. W świetle tego artykułu k.c. poszkodowany może żądać pokrycia kosztów np.:

- leczenia (pobytu w szpitalu, konsultacji u wybitnych specjalistów, leków, rehabilitacji itp.). Jak podaje Swiss Re, koszty leczenia wzrosły na wszystkich rynkach. Jest to związane zarówno ze stosowaniem nowoczesnych procedur, wzrostem cen, jak i niewydolnością publicznej służby zdrowia i wzrostem zakresu usług prywatnych, a także większą świadomością pacjentów (Raport 2011: 31-33). Prawa żądania zwrotu bądź wyłożenia z góry sumy na pokrycie kosztów leczenia nie pozbawia poszkodowanego okoliczność, że korzysta on z lecznictwa publicznego, jeżeli tylko zostanie wykazane, iż celowe jest stosowanie takich metod leczenia, zabiegów lub środków leczniczych, które nie wchodzą w zakres świadczeń z tytułu ubezpieczenia społecznego (Wyrok SN 1969);

- dodatkowych usług pielęgniarskich i opiekuńczych ${ }^{3}$. Zapotrzebowanie na usługi opiekuńcze rośnie razem z poziomem niesamodzielności, od okresowej pomocy w pracach domowych, po pomoc w czynnościach pielęgnacyjnych i stałą obecność innej osoby. Wsparcie instytucyjne jest niewystarczające, a niezaspokojone potrzeby poszkodowanych w wypadkach drogowych obciążają sprawcę szkody, a w konsekwencji ubezpieczyciela (Powała 2010: 23);

\footnotetext{
${ }^{2}$ Roszczenia osób pośrednio poszkodowanych, w związku ze śmiercią bezpośrednio poszkodowanego, obejmują: zadośćuczynienie za krzywdę dla najbliższych członków rodziny; stosowne odszkodowanie - na wypadek pogorszenia się sytuacji życiowej osoby bliskiej; rentę alimentacyjną; zwrot kosztów leczenia i pogrzebu poniesionych przez każdą stronę trzecią.

${ }^{3}$ System opieki zdrowotnej zapewnia osobom niesamodzielnym pomoc w ramach długoterminowej opieki pielęgniarskiej, natomiast system opieki społecznej - domowe usługi opiekuńcze.
} 
- dodatkowego odżywiania w celu wzmożenia procesów leczniczych;

- zakupu niezbędnego sprzętu ortopedycznego i protez;

- dojazdów na wizyty lekarskie i konsultacje;

- dojazdu osób bliskich poszkodowanemu do i ze szpitala (Bentkowska 2003: 17-19).

\section{Zadośćuczynienie za doznaną krzywdę}

Jest to bardzo specyficzny rodzaj odszkodowania o charakterze całościowym, którego zadaniem jest złagodzenie poczucia krzywdy moralnej i cierpień fizycznych, będących następstwem wypadku.

Roszczenie tego typu znajduje oparcie w przepisie artykułu 445 § 1 k.c. w związku z art. 444 k.c. Odszkodowanie w formie zadośćuczynienia realizowane jest przez wypłatę kwoty pieniężnej. Mimo że krzywda, którą ma naprawić zadośćuczynienie, jest niemajątkowa, zaspokojenie roszczeń osoby poszkodowanej następuje w formie majątkowej. W tym tkwi podstawowa trudność związana z ustalaniem zadośćuczynienia. Proces określania kwoty zadośćuczynienia nie może być oparty na sztywnych schematach, powinien uwzględniać przesłanki indywidualne, a nawet subiektywne, bezpośrednio związane z osobą konkretnego poszkodowanego.

Ocena całościowa doznanych krzywd musi opierać się na uwzględnieniu różnych czynników. Do nich należą m.in.: wysokość trwałego uszczerbku na zdrowiu, okres leczenia, indywidualne natężenie cierpień związanych z przebiegiem leczenia, okres rehabilitacji. Brane są pod uwagę również takie czynniki, jak: wiek i płeć poszkodowanego, zawód, możliwości realizacji zawodowej po wypadku oraz sytuacja bytowa poszkodowanego. Szczegółowa analiza wymienionych czynników powinna doprowadzić w efekcie do określenia, jak dalece zmieniła się sytuacja poszkodowanego po wypadku.

Zadośćuczynienie ze względu na funkcję kompensacyjną ma być odczuwalną wartością. Dla osoby, która uległa wypadkowi i otrzymuje zadośćuczynienie, ma ono nie tylko wymiar materialny, lecz także symboliczny. Po otrzymaniu zadośćuczynienia poszkodowany ma uzyskać przekonanie, że jego krzywda została zrekompensowana. Oczywiście nie w sensie dosłownym, ponieważ trwałych następstw zdrowotnych nie da się cofnąć (Celczyńska 2011: 8).

W praktyce zostały wypracowane pewne zasady, które pomagają przy określaniu wysokości zadośćuczynienia. I tak np. przyjmuje się, że kwota zadośćuczynienia nie powinna pozostawać w rażącej dysproporcji do aktualnych przeciętnych warunków społecznych. 


\section{Renta}

Renta jest odszkodowaniem o charakterze periodycznym (okresowym), a podstawa roszczenia wynika z art. $444 \S 2$ i 33 k.c. Warunkiem powstania prawa do renty jest trwały charakter uszkodzenia ciała lub rozstroju zdrowia. W takim przypadku rentę ustala się na czas nieokreślony. Renta może być też ograniczona czasowo, jeśli ustanie skutków wypadku można w miarę dokładnie ustalić.

Na podstawie art. 447 k.c. z ważnych powodów sąd może, na żądanie poszkodowanego, przyznać mu zamiast renty lub jej części, odszkodowanie jednorazowe. Dla osoby poszkodowanej uprawnionej do renty prawo do odszkodowania jednorazowego może być korzystniejsze. Dzięki temu uzyskuje ona bowiem jednorazowo znaczne środki finansowe, które pozwalają na odpowiednie przystosowanie się do nowej sytuacji, w jakiej znalazła się po wypadku. Norma kodeksowa stanowi, że zastosowanie wypłaty jednorazowego odszkodowania winno mieć miejsce szczególnie wówczas, gdy poszkodowany stał się inwalidą, a wypłacona kwota ułatwi mu wykonywanie nowego zawodu. Trzeba zwrócić uwagę, iż nie jest to tożsame z przewidzianą w przepisie art. $444 \S 1$ k.c. możliwością żądania sumy potrzebnej na koszty przygotowania do innego zawodu. Przy tej okazji warto jeszcze zaznaczyć, że renta jako świadczenie wieloletnie wymaga po stronie zakładu ubezpieczeń stałej obsługi przy jej realizacji. Oprócz tego w myśl art. 907 § 2 k.c. w każdej chwili, jeśli zaistnieją ku temu przesłanki, jej wysokość może być rewidowana, co oznacza w praktyce konieczność dokonywania nowych ustaleń faktycznych i wyliczania wartości przysługującego świadczenia ${ }^{4}$.

W punktach: 5. i 6. zostaną szerzej omówione roszczenia z tytułu rent wypłacanych z ubezpieczenia OC posiadaczy pojazdów mechanicznych dla osób bezpośrednio poszkodowanych.

\section{ROSZCZENIA Z TYTUŁU SZKÓD OSOBOWYCH W UJĘCIU ILOŚCIOWYM}

Przedmiot badań obejmuje roszczenia z tytułu szkód osobowych z ubezpieczenia OC posiadaczy pojazdów mechanicznych, obsługiwane przez kancelarię odszkodowawczą , zgłoszone do zakładów ubezpieczeń w 2012 r. Roszczenia te zostały złożone przez 174 osoby bezpośrednio (128) i pośrednio (46) poszkodowane w wypadkach drogowych. Wyniki przeprowadzonej analizy zawiera tab. 1.

\footnotetext{
${ }^{4}$ Monitorowanie przebiegu płatności renty i stała obsługa wiąże się z wymiernymi kosztami ponoszonymi przez zakład ubezpieczeń. W związku z tym w niektórych przypadkach również dla zakładu ubezpieczeń, wypłata odszkodowania jednorazowego może okazać się racjonalniejszym rozwiązaniem, ponieważ daje możliwość szybkiego zakończenia postępowania odszkodowawczego.

${ }^{5}$ Kancelaria odszkodowawcza udostępniła dane bez zgody na publikację jej nazwy.
} 
Rodzaje i liczba roszczeń z tytułu szkód osobowych

\begin{tabular}{|l|c|c|c|c|c|}
\hline \multirow{2}{*}{ Rodzaj roszczenia } & \multirow{2}{*}{ Ogółem } & \multicolumn{5}{c|}{ Kategoria poszkodowanego } \\
\cline { 3 - 6 } & & $\begin{array}{c}\text { kierujący } \\
\text { pojazdem }\end{array}$ & pasażer & pieszy & $\begin{array}{c}\text { pośrednio } \\
\text { poszkodowany }\end{array}$ \\
\hline Zadośćuczynienie z art. 445 k.c. & 126 & 30 & 67 & 29 & - \\
\hline Zadośćuczynienie z art. 446 k.c. & 37 & - & - & - & 37 \\
\hline Stosowne odszkodowanie & 19 & - & - & - & 19 \\
\hline Koszty dojazdu na leczenie & 104 & 26 & 56 & 22 & - \\
\hline Koszty opieki i leczenia & 103 & 26 & 53 & 24 & - \\
\hline Utracony dochód & 42 & 21 & 16 & 5 & - \\
\hline Renta alimentacyjna & 5 & - & - & - & 5 \\
\hline $\begin{array}{l}\text { Renta wyrównawcza i na zwiększone } \\
\text { potrzeby }\end{array}$ & 8 & 3 & 3 & 2 & - \\
\hline Koszty pogrzebu & 10 & - & - & - & 10 \\
\hline Razem & 454 & 106 & 195 & 82 & 71 \\
\hline
\end{tabular}

Źródło: opracowanie na podstawie udostępnionych danych.

Wyodrębniono kategorie wśród osób bezpośrednio poszkodowanych: kierujący pojazdem, pasażer i pieszy. Natomiast pośrednio poszkodowani to osoby dochodzące roszczeń w związku ze śmiercią bezpośrednio poszkodowanego.

Dominującym roszczeniem, jakiego dochodzą bezpośrednio poszkodowani, jest zadośćuczynienie (98\% poszkodowanych domaga się tego świadczenia). $\mathrm{Na}$ drugim miejscu są: zwrot kosztów opieki i leczenia $(81 \%)$ oraz zwrot kosztów dojazdu na leczenie (81\%). O wyrównanie utraconego dochodu ubiega się 33\% bezpośrednio poszkodowanych (z czego połowa to osoby kierujące pojazdem). Natomiast o przyznanie świadczeń rentowych stara się $6 \%$.

W grupie osób pośrednio poszkodowanych $80 \%$ zgłosiło roszczenia z tytułu zadośćuczynienia, a 41\% o stosowne odszkodowanie. Z kolei 11\% domaga się renty alimentacyjnej.

\section{RENTA Z TYTUŁU CAŁKOWITEJ BADŹ CZEŚCIOWEJ UTRATY ZDOLNOŚCI POSZKODOWANEGO DO PRACY ZAROBKOWEJ}

Tego rodzaju renta ma największe znaczenie. Ma wynagrodzić szkodę o charakterze trwałym polegającą na utracie spodziewanych korzyści przez określony czas lub nawet dożywotnio. 
Powstanie szkody polegającej na utracie lub zmniejszeniu dochodów następuje z chwilą, gdy poszkodowany został po raz pierwszy pozbawiony możliwości uzyskania zarobków i innych korzyści, jakie osiągałby, gdyby nie doznał uszkodzenia ciała lub rozstroju zdrowia.

Przy ustalaniu wymiaru renty badane są następujące okoliczności:

- zawód poszkodowanego;

- kwalifikacje zawodowe poszkodowanego;

- wiek;

- stopień ograniczenia zdolności do pracy;

- stan zdrowia poszkodowanego przed zdarzeniem;

- perspektywy związane z miejscem pracy (kondycja ekonomiczna zakładu, zasady wynagradzania, awansów, podwyższania kwalifikacji itp.).

Jak wspomniano wcześniej, dla powstania renty następstwa uszkodzenia ciała lub rozstroju zdrowia muszą mieć charakter trwały, ale niekoniecznie nieodwracalny. W świetle wyroków sądowych poszkodowany nie może być zmuszony do poddania się zabiegowi operacyjnemu w celu przywrócenia w całości lub częściowo zdolności do pracy; decyzja w tym względzie należy wyłącznie do niego, wobec czego odmowa poddania się zabiegowi nie może mieć wpływu na wysokość odszkodowania (Wyrok SN 1961). Jednakże w przypadku wypróbowanego i powszechnie stosowanego zabiegu medycznego, o minimalnym stopniu ryzyka, uzasadniona będzie ocena odmienna (Wyrok SN 1978).

\section{RENTA Z TYTULU ZWIĘKSZENIA SIE POTRZEB POSZKODOWANEGO}

W przepisie art. 444 § 2 k.c., stanowiącym, iż poszkodowany, u którego nastąpiło w wyniku wypadku zwiększenie potrzeb, może żądać od zobowiązanego do naprawienia szkody odpowiedniej renty. Pojęcie zwiększonych potrzeb nie zostało sprecyzowane. W praktyce mogą to być zatem różne stany faktyczne, zależne od tego, w jakiej sytuacji powypadkowej znajduje się poszkodowany.

Wskutek zdarzenia poszkodowany może ponieść szkodę polegającą na konieczności ponoszenia stałych wydatków (koszty opieki, lepszego odżywiania, korzystania z droższych środków komunikacji, korepetycji, zakupu leków, rehabilitacji, specjalnej diety, konsultacji lekarskich itp.). Taka sytuacja daje poszkodowanemu samodzielne roszczenie o rentę.

Przyznanie renty z tytułu zwiększonych potrzeb na podstawie art. $444 \S 2$ k.c. nie jest uzależnione od wykazania, że poszkodowany potrzeby te faktycznie zaspokaja i ponosi związane z tym wydatki. Do przyznania renty z tego tytułu wystarcza samo istnienie zwiększonych potrzeb jako następstwo czynu niedozwolonego (Wyrok SN 1976). Z reguły są to potrzeby związane ze stanem zdrowia osoby poszkodowanej. 
Tak określone potrzeby mogą występować, np. przez krótki czas, bezpośrednio po wypadku. Wtedy ich zaspokojenie może przybrać formę jednorazową na podstawie art. $444 \S 1$ k.c. Jeżeli jednak będą miały charakter powtarzalny i jednocześnie zostanie ustalone, że poszkodowany wymaga stałego ich zaspokajania, to obowiązek odszkodowawczy przybiera formę renty (Chmielowiec 2011: 11-12).

\section{RENTA Z TYTULU ZMNIEJSZANIA SIE WIDOKÓW POWODZENIA NA PRZYSZLOŚĆ}

Zmniejszenie widoków na przyszłość stanowi szkodę przyszłą i wyrażać się musi również uszczerbkiem majątkowym, polegającym na utracie innych korzyści majątkowych, jakie poszkodowany dzięki swoim indywidualnym właściwościom (np. przez uzyskanie szczególnie wysokich kwalifikacji lub specjalizacji, przez posiadanie szczególnych uzdolnień, talentu itp.) mógłby przy pełnej sprawności organizmu osiągnąć, a których osiągnięcie stało się na skutek doznanego uszkodzenia ciała lub rozstroju zdrowia niemożliwe.

Zmniejszenie się widoków powodzenia na przyszłość może być samoistną podstawą zasądzenia renty wyrównawczej, jeżeli istnieje związek pomiędzy utratą szans a ograniczeniem na przyszłość - w stosunku do sytuacji przed szkodą - możliwości zarobkowych, przy zachowanej (choćby całkowicie) przez poszkodowanego zdolności do pracy (np. oszpecenie aktora, zmniejszenie sprawności fizycznej trenera sportowego itp.). Często jednak przesłanka ta będzie towarzyszyła innym podstawom przyznania renty, w szczególności w cięższych przypadkach uszkodzenia ciała lub rozstroju zdrowia, stanowiąc dodatkową okoliczność uzasadniającą przyznanie świadczeń rentowych w odpowiedniej wysokości (np. jeżeli sam fakt doznanego kalectwa zmniejsza obiektywnie szanse podjęcia pracy w zawodzie dotychczas wykonywanym przez poszkodowanego).

\section{EMPIRYCZNA ANALIZA ŚWIADCZEŃ RENTOWYCH}

Badanie przeprowadzono na podstawie danych z jednostki terenowej zakładu ubezpieczeń ${ }^{6}$. Okres poddany badaniu to trzy kolejne lata (okresy sprawozdawcze). Wstępnym etapem jest prezentacja badanego portfela ubezpieczeń OC posiadaczy pojazdów mechanicznych według liczby ryzyk i szkód (tab. 2).

\footnotetext{
${ }^{6}$ Zakład ubezpieczeń udostępnił dane bez zgody na publikację nazwy.
} 
Liczebność próby badawczej

\begin{tabular}{|c|c|c|}
\hline Okres sprawozdawczy & Liczba ryzyk & Liczba szkód \\
\hline 2010 & 45890 & 1485 \\
\hline 2011 & 42169 & 1247 \\
\hline 2012 & 41520 & 1094 \\
\hline Ogółem & 129579 & 3826 \\
\hline
\end{tabular}

Uwaga: liczba ryzyk - liczba ubezpieczonych pojazdów; liczba szkód - liczba roszczeń o odszkodowanie zgłoszonych przez poszkodowanych, które zostały spełnione (nastąpiła wypłata odszkodowania lub świadczenia rentowego w okresie sprawozdawczym, z wyłączeniem szkód odmówionych).

Źródło: opracowanie na podstawie udostępnionych danych.

Zauważalna jest tendencja spadkowa zarówno w przypadku liczby ryzyk, jak i liczby szkód. Częstość szkód ${ }^{7}$ również charakteryzuje się taką tendencją, tj. na każde 100 ryzyk wypłacone zostało 3,2 szkód w roku 2010, w roku 2011 - 3 szkody, a w 2012 wskaźnik ten wyniósł 2,6\%.

Poziom kosztów w postaci wypłaconych odszkodowań, jaki został wygenerowany w badanej próbie, zawiera tab. 3 .

Tabela 3

Wartość odszkodowań i rent

\begin{tabular}{|c|c|c|}
\hline Okres sprawozdawczy & Odszkodowania (w zł) & Renty (w zł) \\
\hline 2010 & 7101452 & 440945 \\
\hline 2011 & 5938340 & 473056 \\
\hline 2012 & 5636407 & 521437 \\
\hline Ogółem & 18676199 & 1435438 \\
\hline
\end{tabular}

Uwaga: odszkodowania - kwota wypłaconych odszkodowań i świadczeń rentowych w okresie sprawozdawczym; renty - kwota wypłaconych świadczeń rentowych w okresie sprawozdawczym.

Źródło: opracowanie na podstawie udostępnionych danych.

W wartości wypłaconych odszkodowań odnotowuje się spadek. Jest to związane zarówno ze spadkiem liczby szkód, jak i wskaźnika częstości. Natomiast w odniesieniu do wartości wypłaconych świadczeń rentowych zauważalna jest

\footnotetext{
${ }^{7}$ Relacja liczby szkód wypłaconych do liczby ryzyk wyrażona w procentach.
} 
tendencja wzrostowa. Kwota wypłaconych rent w 2012 r. wzrosła o ponad 18\% w stosunku do roku 2010.

Udział wypłaconych świadczeń rentowych w wypłaconych odszkodowaniach (odszkodowania łącznie ze świadczeniami rentowymi) wynosił: w roku 2010 $-6,2 \%$, w roku $2011-7,5 \%$, a w $2012-9,2 \%$.

Znaczącą rolę w odniesieniu do świadczeń z tytułu szkód osobowych przypisuje się rentom z uwagi na ich wieloletni charakter. Szczegółowe dane z tego obszaru znajdują się w tab. 4.

Tabela 4

Świadczenia rentowe wypłacone

\begin{tabular}{|c|c|c|c|c|c|c|c|c|c|}
\hline \multirow[b]{2}{*}{$\begin{array}{l}\text { Renty } \\
\text { z roku }\end{array}$} & \multicolumn{3}{|c|}{2010} & \multicolumn{3}{|c|}{2011} & \multicolumn{3}{|c|}{2012} \\
\hline & liczba & $\begin{array}{l}\text { kwota } \\
\text { (w zf) }\end{array}$ & $\begin{array}{c}\text { średnia } \\
\text { renta } \\
\text { (w zł) }\end{array}$ & liczba & $\begin{array}{l}\text { kwota } \\
\text { (w zl) }\end{array}$ & $\begin{array}{c}\text { średnia } \\
\text { renta } \\
\text { (w zl) }\end{array}$ & liczba & $\begin{array}{l}\text { kwota } \\
\text { (w zl) }\end{array}$ & $\begin{array}{c}\text { średnia } \\
\text { renta } \\
\text { (w zl) }\end{array}$ \\
\hline 2012 & - & - & - & - & - & - & - & - & - \\
\hline 2011 & - & - & - & 2 & 9302 & 4651 & 5 & 25527 & 5085 \\
\hline 2010 & - & - & - & 1 & 5000 & 5000 & 2 & 24870 & 12435 \\
\hline 2009 & 8 & 34110 & 4264 & 8 & 35080 & 4385 & 9 & 44159 & 4906 \\
\hline 2008 & 9 & 55980 & 6220 & 8 & $\begin{array}{ll}60 & 100\end{array}$ & 7512 & 9 & 62816 & 6979 \\
\hline 2007 & 4 & 27560 & 6890 & 4 & 27560 & 6890 & 4 & 27560 & 6890 \\
\hline 2006 & 6 & 29685 & 4947 & 5 & 30562 & 6112 & 7 & 32754 & 4679 \\
\hline 2005 & 11 & 67750 & 6775 & 11 & 67750 & 6775 & 10 & 64687 & 6469 \\
\hline 2004 & 9 & 31820 & 3535 & 7 & 28670 & 4096 & 8 & 33594 & 4199 \\
\hline $\begin{array}{r}2003 \mathrm{i} \\
\text { lat wcz. }\end{array}$ & 55 & 194040 & 3528 & 53 & 209032 & 3944 & 54 & 205470 & 3805 \\
\hline Ogółem & 102 & 440945 & 4323 & 99 & $473 \quad 056$ & 4778 & 108 & 521437 & 4828 \\
\hline
\end{tabular}

Uwaga: średnia renta - kwota wypłaconych świadczeń rentowych w skali roku do liczby rent.

Źródło: opracowanie na podstawie udostępnionych danych.

Świadczenia rentowe ze zdarzeń zaistniałych w roku 2003 i wcześniej stanowią ok. 50\% ogólnej liczby rent w każdym okresie sprawozdawczym.

Analizując kwoty wypłaconych rent, odnotowuje się ich wzrost zarówno w roku 2011, jak i 2012, odpowiednio o 7\% i 10\%. Przeprowadzone badania wykazują również wzrost przeciętnej wartości wypłacanego świadczenia rentowego. Można nawet zauważyć wzrost średniej kwoty rent pochodzących z tzw. 
"starego portfela", tj. z roku 2003 i lat wcześniejszych. Kwota ta wyniosła 3805 zł w 2012 r. Najwyższą wartość przeciętnego świadczenia rentowego odnotowano w 2012 r., tj. 12435 zł. Są to świadczenia z tytułu szkód zaistniałych w $2010 \mathrm{r}$.

W odniesieniu do szkód osobowych realizacja świadczeń (w tym rentowych) często następuje na podstawie wyroku sądowego. Biorąc po uwagę długość trwania procesów sądowych, to okres realizacji tego typu szkód wynosi nawet kilka lat. Abstrahując od spraw sądowych, generalnie w przypadku szkód osobowych zarówno okres inkubacji ${ }^{8}$, jak i realizacji jest zdecydowanie dłuższy niż w przypadku szkód rzeczowych.

\section{PODSUMOWANIE}

W problematykę bezpieczeństwa na polskich drogach zaangażowanych jest wiele różnych podmiotów. Stosowane są rygorystyczne przepisy dotyczące zasad ruchu drogowego, doskonalona jest działalność prewencyjna, a mimo to wypadków i ich negatywnych skutków nie da się całkowicie wyeliminować. W takiej sytuacji uwidoczniona zostaje korzyść funkcjonowania zakładów ubezpieczeń oraz innych instytucji ${ }^{9}$, które łagodzą następstwa zdarzeń w ruchu drogowym.

Istotne znaczenie społeczne w łagodzeniu konsekwencji wypadków drogowych mają świadczenia rentowe wypłacane z ubezpieczenia OC posiadaczy pojazdów mechanicznych przez zakłady ubezpieczeń. Jak wynika z przeprowadzonego badania, udział rent w ogólnej kwocie wypłacanych odszkodowań z przedmiotowego ubezpieczenia nie jest duży i mieści się w przedziale od $6,2 \%$ do $9,2 \%$, ale należy jeszcze raz zaakcentować wieloletni charakter rent. Na uwagę zasługuje też rosnąca tendencja, jaką zauważono w uzyskanych wynikach z przedmiotowego obszaru (średnia renta, wartość wypłaconych rocznie świadczeń rentowych). Tendencja ta może wiązać się z faktem zwiększania się świadomości ubezpieczeniowej/prawnej poszkodowanych, również przy znaczącym udziale funkcjonujących na polskim rynku kancelarii odszkodowawczych.

\footnotetext{
${ }^{8}$ Inkubacja szkód - liczba dni od powstania szkody do daty jej zgłoszenia.

${ }^{9}$ Jedną z takich instytucji, której zadania są znaczącym uzupełnieniem ochrony osób trzecich - poszkodowanych i uprawnionych do tytułu zdarzeń ubezpieczeniowych, obejmowanych ochroną w ramach obowiązkowego ubezpieczenia odpowiedzialności cywilnej posiadaczy pojazdów mechanicznych jest Ubezpieczeniowy Fundusz Gwarancyjny.
} 


\title{
BIBLIOGRAFIA
}

Bentkowska D. (2003), Roszczenia osobowe przystugujace poszkodowanym w wypadkach drogowych oraz osobom uprawnionym, „Prawo Asekuracyjne”, nr 1, s. 15-25.

Bieniek G. (2011), Odpowiedzialność cywilna za wypadki drogowe, Warszawa.

Celczyńska A. (2011), Świadczenia z tytułu zadośćuczynienia dla poszkodowanych $w$ wypadkach drogowych, „Folia Oeconomica”, nr 244, s. 5-16.

Chmielowiec B. (2011), Renta na zwiększone potrzeby w świetle orzecznictwa sądów powszechnych i Sądu Najwyższego, „Monitor Ubezpieczeniowy”, nr 46, s. 11-13.

Czachórski W. (1995), Zobowiąania. Zarys wykładu, Warszawa.

Kwiecień I. (2010), Czynniki determinujące skuteczność transferu ryzyka poniesienia ciężaru kompensacji szkód na osobie poprzez obowiązkowe ubezpieczenie odpowiedzialności cywil$n e j$, „Wiadomości Ubezpieczeniowe”, nr 4, s. 5-27.

Maciąg A. (2008), Szacowanie kosztów leczenia ofiar wypadków drogowych w Polsce, www.gambit.fril.org.pl/files/Gambit_2008.pdf (dostęp: 8.08.2014).

Maśniak D. (2010), Transgraniczny system ochrony ofiar wypadków drogowych, Warszawa.

Olędzka A. (2012), Obniżenie wartości handlowej pojazdu po naprawie a odszkodowanie z tytułu ubezpieczenia komunikacyjnego OC, „Wiadomości Ubezpieczeniowe”, nr 1, s. 31-45.

Powała D. (2010), Propozycje sposobu oceny potrzeb i zakresu opieki nad poszkodowanym po urazie komunikacyjnym, www.ptmu.org.pl/pliki/ptmu_konf_201010_program_nowy_v2.pdf (dostęp: 10.08.2014).

Raport (2011), Szkody osobowe z tytułu OC komunikacyjnego w Polsce. Tendencje rozwoju 20062009, PRO MOTOR, Warszawa.

Rybicki Z. (red.), (1980), Mała Encyklopedia Prawa, Warszawa.

Ustawa z dnia 22 maja 2003 r. o ubezpieczeniach obowiązkowych, Ubezpieczeniowym Funduszu Gwarancyjnym i Polskim Biurze Ubezpieczycieli Komunikacyjnych, Dz. U. 2003 nr 124 poz. 1152 z późn. zm.

Ustawa z dnia 23 kwietnia 1964 r. - Kodeks cywilny, Dz. U. 1964 nr 16, poz. 93 z późn. zm.

Wyrok Sądu Najwyższego z dnia 15.03.1961, II CR 867/59, OSP 1962, nr 2, poz. 10.

Wyroku Sądu Najwyższego z dnia 26.06.1969, II PR 212/69, OSNCP 1970, nr 3, poz. 50.

Wyrok Sądu Najwyższego z dnia 11.03.1976, IV CR 50/70, OSNCP 1977, nr 1, poz. 11.

Wyrok Sądu Najwyższego z dnia 11.01.1978, III PR 183/77, OSP 1979, nr 1, poz. 17.

\section{Anna Celczyńska}

\section{PENSION BENEFITS FOR PARTIES DIRECTLY INJURED IN ROAD ACCIDENTS}

\begin{abstract}
Road accidents are a serious social problem. At present, highly-developed countries believe victims of road traffic should be treated not as a side effect of increased mobility but an important public health issue. The paper presents both the interpretive and quantitative analyses of claims of parties injured in road accidents as well as the current trend in the field of pension benefits.
\end{abstract}

Keywords: treatment costs, pension benefits, road accidents. 